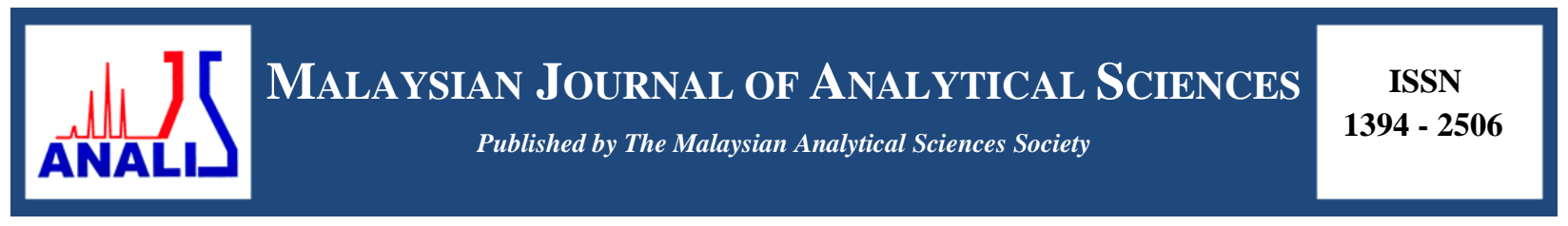

\title{
SYNTHESIS AND ANTIMICROBIAL ACTIVITIES OF ELEVEN $N$-SUBSTITUTED MALEIMIDES
}

\author{
(Sintesis dan Kajian Antimikrob Terhadap Sebelas Terbitan Maleimida) \\ Tang Sook Chin, Fatin Ilyani Nasir, Nurul Izzaty Hassan* \\ School of Chemical Sciences and Food Technology, \\ Faculty of Science and Technology, \\ Universiti Kebangsaan Malaysia, 43600 UKM Bangi, Selangor, Malaysia \\ *Corresponding author: drizz@ukm.edu.my
}

Received: 13 January 2016; Accepted: 4 April 2016

\begin{abstract}
The antimicrobial activities of eleven maleimide derivatives were tested in this study. Out of the eleven samples, $N$-(4fluorophenyl) maleimide, $N$-(4-chlorophenyl) maleimide and $N$-(4-bromophenyl) maleimide were synthesized by reacting maleic anhydride with 4-fluorophenylaniline, 4-chlorophenylaniline and 4-bromophenylaniline, respectively in the presence of acetic acid, by refluxing overnight. Crystals were successfully obtained after the products were recrystallized with different mixture of solvents. Their chemical structures were confirmed by infrared spectroscopy (IR), ${ }^{1} \mathrm{H}$ and ${ }^{13} \mathrm{C}$ Nuclear Magnetic Resonance (NMR) and melting point determination. Subsequently, all the samples were screened for their biological activity using disc diffusion method. The bacteria chosen for this study were Gram-negative Escherichia coli, Gram-positive Bacillus subtilis and yeast Saccharomyces cerevisae. Positive control for bacteria was streptomycin and nystatin for the yeast. M1 to M6 compounds gave remarkable result at low concentrations whereas M8, M9 and M11 compounds are mostly inactive up to a high concentration. In contrast, the unsubstituted maleimide, M7 was highly reactive towards both bacteria and yeast at low and high concentrations.
\end{abstract}

Keywords: $N$-substituted maleimide, antimicrobial, disc diffusion

\section{Abstrak}

Kajian antimikrob terhadap sebelas terbitan $N$-maleimida telah diuji dalam kajian ini. Tiga daripada sebelas sebatian maleimida yang diuji, iaitu $N$-(4-florofenil)maleimida, $N$-(4-klorofenil)maleimida dan $N$-(4-bromofenil)maleimida telah disintesis melalui tindakbalas maleik anhidrida dengan 4-florofenilanilina, 4-klorofenilanilina and 4-bromofenilanilina secara berasingan dalam kehadiran asid asetik, diikuti dengan refluks semalaman. Mendakan tidak berwarna telah diperolehi setelah penghabluran semula dilakukan ke atas hasil sintesis. Pencirian struktur sebatian dilakukan melalui kaedah spektroskopi Infra Merah (IR), ${ }^{1} \mathrm{H}$ dan ${ }^{13} \mathrm{C}$ Resonans Magnet Nukleus (NMR) dan penentuan takat lebur. Seterusnya, kajian antimikrob bagi kesemua sebelas sampel dilakukan melalui kaedah resapan cakera. Bakteria yang digunakan dalam kajian ini ialah Escherichia coli dan Bacillus subtilis manakala yis yang digunakan ialah Saccharomyces cerevisae. Kawalan positif untuk bakteria ialah streptomisin dan nystatin untuk yis. Sebatian M1 ke M6 mencatatkan keaktifan yang baik pada kepekatan rendah. Sebatian M8, M9 dan M11 kebanyakannya tidak menunjukkan keaktifan walaupun kepekatan dos ditingkatkan. Berbeza pula dengan sebatian M7, iaitu maleimida yang tidak mempunyai sebarang kumpulan gantian yang menunjukkan keaktifan yang tinggi terhadap kedua-dua bakteria dan yis pada kepekatan rendah dan tinggi.

Kata kunci: maleimida $N$-gantian, antimikrob, kaedah resapan cakera 


\section{Introduction}

Microbe resistance has been a challenge for health practitioner and the pharmaceutical industry. The prescription of antibiotics are reported to be related to bacterial resistance. The most commonly found drug-resistant bacteria in hospitals are methicilin-resistant Staphylococcus aureus (MRSA) and Pseudomonas aeruginosa [1]. The resistance towards various drugs and medicines shown by bacteria and fungi has also become the main reason for failure in chemotherapy of infectious diseases. Therefore, the need for a novel anti microbe agent is highly desirable.

Recently, researchers are focusing on bacterial and fungal enzymes that are responsible for catalysing important biochemical reactions in microbe cells. Biologically active compounds capable of deactivating these enzymes and block the metabolic pathway of these bacteria and fungi selectively in human body are potential novel antimicrobial drugs [2]. Many biologically active compounds including most of the antibiotics are enzyme inhibitors. Compounds that are active towards the thiol group are able to inhibit cysteine protease and other proteins containing important cysteins. Maleimides for instance, portrayed the ability to inhibit cysteine protease and $N$-ethylmaleimide specifically, acts spontaneously and fast with the sulphydryl group.

Cyclic imides such as succinimides, maleimides, phthalimides and their derivatives have an imide ring and the CO-N(R)-CO- structure that gives them neutrality and hydrophobicity. Previous studies have shown that various kinds of biological activities such as antibacterial, antifungal and antitumor are related to these compounds and their derivatives as shown in Table 1 [3]. Maleimide compounds in specific have shown antifungal and antibacterial properties [4], ability to inhibit Protein Kinase C and antitumor property [5], and analgesic activity [6]. Li research group mentioned about the antifungal activity of simple compounds with dimethylmaleimide structure against Botrytis cinerea, which revealed that natural products containing maleimide structure has high biological activity while non-natural products having maleimide structure also shows antifungal activity [7].

Table 1. Antimicrobial activity of $N$-substituted maleimide

\begin{tabular}{|c|c|c|c|}
\hline \multirow[t]{2}{*}{ Types of Maleimide } & \multicolumn{3}{|c|}{ Types of Microbe } \\
\hline & E. coli & B. subtilis & S. cerevisiae \\
\hline$N$-(4-chlorophenyl) maleimide & - & - & MIC: $3.90 \mu \mathrm{g} / \mathrm{mL}^{[10]}$ \\
\hline$N$-(4-florophenyl) maleimide & - & - & MIC: $3.90 \mu \mathrm{g} / \mathrm{mL}^{[10]}$ \\
\hline$N$-(4-bromophenyl) maleimide & MIC: $128 \mu \mathrm{g} / \mathrm{mL}^{[2]}$ & MIC: $64 \mu \mathrm{g} / \mathrm{mL}^{[2]}$ & $\begin{array}{l}\text { MIC: } 1.0 \mu \mathrm{g} / \mathrm{mL}^{[2]} \\
\text { MIC: } 7.81 \mu \mathrm{g} / \mathrm{mL}^{[10]}\end{array}$ \\
\hline$N$-(2-methylphenyl) maleimide & - & - & MIC: $7.81 \mu \mathrm{g} / \mathrm{mL}^{[10]}$ \\
\hline$N$-(4-methylphenyl) maleimide & - & - & MIC: $3.90 \mu \mathrm{g} / \mathrm{mL}^{[10]}$ \\
\hline$N$-(tert-butyl) maleimide & MIC: $32 \mu \mathrm{g} / \mathrm{mL}^{[2]}$ & $\mathrm{MIC}: 2.0 \mu \mathrm{g} / \mathrm{mL}^{[2]}$ & MIC: $2.0 \mu \mathrm{g} / \mathrm{mL}^{[2]}$ \\
\hline$N$-methylmaleimide & - & - & MIC: $7.81 \mu \mathrm{g} / \mathrm{mL}^{[2]}$ \\
\hline
\end{tabular}

Studies have also reported that some of the maleimide derivatives that is biologically active is neither haemolytic nor cytotoxic towards the human cancer cell, which indicated the selectivity of action of maleimides towards fungal pathogen [8]. Zentz et al. has reported that $N$-substituted maleimides, $N$-(tert-butyl)maleimide in particular shows antibacterial properties towards Escherichia coli. [9].

Maleimide compounds are Michael acceptors prone to be attacked at the double bond in the maleimide ring, by nucleophilic species such as the thiol group as shown in Figure 1. The maleimides react specifically on biological molecules containing thiol group and form stable conjugate protein through thioether bond [11]. The thioether bond formed has strong $\mathrm{C}-\mathrm{S}$ bond which is often irreversible and cannot be reduced by reducing agents. This reaction takes place specifically at $\mathrm{pH} 6.5-7.5$. in alkaline condition when $\mathrm{pH}$ exceeds 8.5 , hydrolysis of maleimide to maleimic acid is prone to take place [12]. 

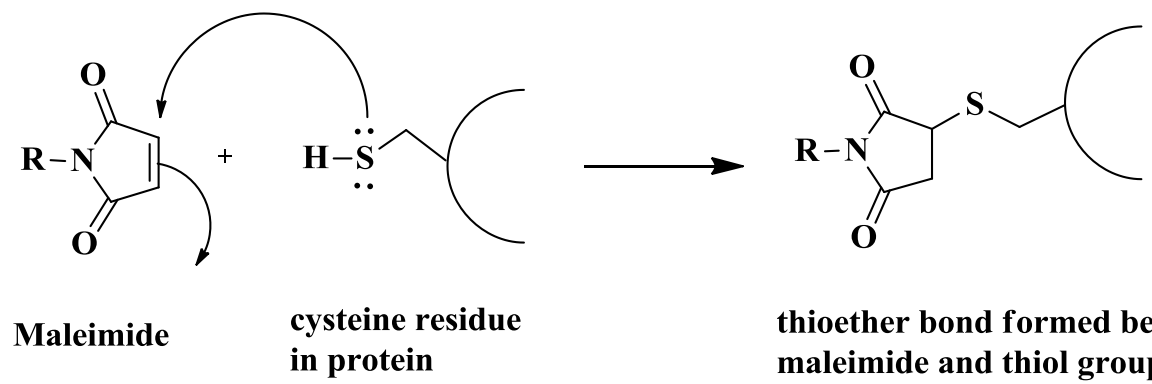

thioether bond formed between maleimide and thiol group

Figure 1. Reaction between maleimide and thiol group

Many types of active protein and enzymes can be found on bacteria cell membrane. When these enzymes react with foreign substances such as drugs, their enzyme activity will change and subsequently inhibit its growth [13].

In this study, we focused on $N$-substituted maleimides, which refer to any maleimide compounds that has substituent groups such as alkyl or halides attached to the nitrogen atom in the maleimide ring. Since biological activitiy of each maleimide derivatives varies from one another, the structure activity relationship display distinct properties that will affect the reactivity of different maleimide compounds. Some of the factors responsible for the different reactivities of maleimide compounds are the presence of aryl group on the nitrogen atom in the maleimide ring [5], the length of alkyl chain on the alkylphenyl group attached to the nitrogen atom in the maleimide ring [7], the lipophilicity and bulkiness of the compound molecule [2] and the presence of any substituents on the maleimide ring [14].

In view of this, 11 samples of $N$-substituted maleimides (M1 to M11) have been tested on three different microbes, namely Escherichia coli (Gram negative), Bacillus subtilis (Gram positive) and Saccharomyces cerevisiae through the disc diffusion method to study the inhibition ability of these samples.

\section{Synthesis of $\mathrm{N}$-(2-methylphenyl)maleimide (M1)}

\section{Materials and Methods}

Maleic anhydride $(44.0 \mathrm{mmol})$ was reacted with $o$-toluidine $(42.3 \mathrm{mmol})$ by dissolving the mixture in THF $(50 \mathrm{~mL})$. The reaction mixture was stirred overnight at room temperature (RT) under nitrogen atmosphere. The precipitate formed was filtered and used in next reaction without further purification. The reaction mixture (1.71 mmol) was suspended in dry acetonitrile $(40 \mathrm{~mL})$ before the addition of zinc bromide $(1.71 \mathrm{mmol})$ and HMDS (8.55 mmol) and heated at $90{ }^{\circ} \mathrm{C}$ for 2 hours before it was allowed to cool to RT and filtered. Subsequently, water (25 mL) was added and acidified with $1 \mathrm{M} \mathrm{HCl}$ until $\mathrm{pH} 1$. The mixture was washed with ethyl acetate $(3 \times 50 \mathrm{~mL})$ and the organic layer was dried over anhydrous $\mathrm{MgSO}_{4}$, filtered and concentrated in vacuo to obtain black solution. The solution was recrystallized to yield colourless crystalline solid (35\%).

\section{Synthesis of N-(3-methylphenyl)maleimide (M2)}

Maleic anhydride $(44.0 \mathrm{mmol})$ was reacted with $m$-toluidine $(42.3 \mathrm{mmol})$ by dissolving the mixture in THF (50 $\mathrm{mL})$. The reaction mixture was stirred overnight at RT under nitrogen atmosphere. The precipitate formed was filtered and used in next reaction without further purification. The reaction mixture (1.71 mmol) was suspended in dry acetonitrile $(40 \mathrm{~mL})$ before the addition of zinc bromide $(1.71 \mathrm{mmol})$ and HMDS $(8.55 \mathrm{mmol})$ and heated at 90 ${ }^{\circ} \mathrm{C}$ for 2 hours before it was allowed to cool to RT and filtered. Subsequently, water (25 mL) was added and acidified with $1 \mathrm{M} \mathrm{HCl}$ until $\mathrm{pH} 1$. The mixture was washed with ethyl acetate $(3 \times 50 \mathrm{~mL})$ and the organic layer was dried over anhydrous $\mathrm{MgSO}_{4}$, filtered and concentrated in vacuo to yield yellowish crystalline solid (28\%). 


\section{Synthesis of $N$-(4-methylphenyl)maleimide (M3)}

Maleic anhydride $(44.0 \mathrm{mmol})$ was reacted with $p$-toluidine $(42.3 \mathrm{mmol})$ by dissolving the mixture in THF $(50 \mathrm{~mL})$. The reaction mixture was stirred overnight at RT under nitrogen atmosphere. The precipitate formed was filtered and used in next reaction without further purification. The reaction mixture $(1.71 \mathrm{mmol})$ was suspended in dry acetonitrile $(40 \mathrm{~mL})$ before the addition of zinc bromide $(1.71 \mathrm{mmol})$ and HMDS $(8.55 \mathrm{mmol})$ and heated at $90{ }^{\circ} \mathrm{C}$ for 2 hours before it was allowed to cool to RT and filtered. Subsequently, water $(25 \mathrm{~mL})$ was added and acidified with $1 \mathrm{M} \mathrm{HCl}$ until $\mathrm{pH} 1$. The mixture was washed with ethyl acetate $(3 \times 50 \mathrm{~mL})$ and the organic layer was dried over anhydrous $\mathrm{MgSO}_{4}$, filtered and concentrated in vacuo to obtain yellow powder. The solution was recrystallized to yield yellow needle-like crystalline solid $(84 \%)$.

\section{Synthesis of $N$-(4-florophenyl)maleimide (M4)}

Maleic anhydride $(9.0 \mathrm{mmol})$ was reacted with equimolar of 4-fluoroaniline by dissolving the mixture in $50 \mathrm{~mL}$ acetic acid at RT. The reactants are stirred for 6.5 hours. The resulting suspension was refluxed overnight for 17.5 hours at $130{ }^{\circ} \mathrm{C}$ and then cooled to room temperature. The resulting solution of maleimide was extracted with ethyl acetate $(3 \times 50 \mathrm{~mL})$. Extracts were combined and recrystallized $(40 \%)$.

\section{Synthesis of $\boldsymbol{N}$-(4-chlorophenyl)maleimide (M5)}

Maleic anhydride $(7.84 \mathrm{mmol})$ was reacted with equimolar of 4-chloroaniline by dissolving the mixture in $50 \mathrm{~mL}$ acetic acid at RT. The reactants are stirred for 5.5 hours at $130{ }^{\circ} \mathrm{C}$ and then cooled to room temperature. The resulting solution of maleimide was extracted with ethyl acetate $(3 \times 50 \mathrm{~mL})$. Extracts were combined and recrystallized $(45 \%)$.

\section{Synthesis of $N$-(4-bromophenyl)maleimide (M6)}

Maleic anhydride $(5.81 \mathrm{mmol})$ was reacted with equimolar of 4-bromoaniline by dissolving the mixture in $50 \mathrm{~mL}$ acetic acid at RT.The reactants are stirred for 5.5 hours at $130{ }^{\circ} \mathrm{C}$ and then cooled to room temperature. The resulting solution of maleimide was extracted with ethyl acetate $(3 \times 50 \mathrm{~mL})$. Extracts were combined and recrystallized $(51 \%)$.

\section{Synthesis of 1-(3,5-bis(trifloromethyl)phenyl)-3-(4-(3-(2,5-dioxo-2H-pirol-1(5H)-yl)phenetyl)phenyl)urea (M8) \\ 4'-ethylene dianiline $(1.08 \mathrm{~g}, 5.1 \mathrm{mmol})$ in dry $\mathrm{CH}_{2} \mathrm{Cl}_{2}(20 \mathrm{~mL})$ was slowly reacted with 3,5-dimethyl phenylisocyanate $(0.5 \mathrm{~g}, 3.4 \mathrm{mmol})$ at $-5^{\circ} \mathrm{C}$ and allowed to stir at ambient temperature for 16 hours. The solvent was removed under reduced pressure. The residue was then purified by column chromatography $\left(\mathrm{CH}_{2} \mathrm{Cl}_{2}\right.$ : $\mathrm{EtOAc}$, $8: 1)$. The product was obtained as yellow solid was dissolved in THF $(10 \mathrm{~mL})$ before reacted with maleic anhydride $(82 \mathrm{mg}, 0.84 \mathrm{mmol})$. The reaction mixture was stirred at ambient temperature under a Ar atmosphere for 3 hours. The precipitate was filtered and the compound obtained $(460 \mathrm{mg}, 98 \%)$ was carried out to the next step without further purification. The acid derivative $(0.20 \mathrm{~g}, 0.35 \mathrm{mmol})$ was dissolved in dry $\mathrm{CH}_{3} \mathrm{CN}(10 \mathrm{~mL})$ and refluxed for 1 hour after the subsequent addition of $\mathrm{ZnBr}_{2}(80 \mathrm{mg}, 0.35 \mathrm{mmol})$ and hexamethyldisilazone $(0.38 \mathrm{~mL}, 1.77 \mathrm{mmol})$. The reaction mixture was filtered and the filtrate was reduced to $10 \%$. The solution was acidified with $0.5 \mathrm{M}$ HCI until $\mathrm{pH} 1$ and extracted into $\mathrm{CH}_{2} \mathrm{CI}_{2}$. The organic layer were combined and dried over $\mathrm{MgSO}_{4}$. The solvent was evaporated in vacuo to give the maleimide $\mathbf{M 8}$ as yellow solid (78\%).}

\section{Synthesis of 1-(4-(4-(2,5-dioxo-2H-pirol-1(5H)-yl)phenetyl)phenyl)-3-(3,5-dimethylphenyl)urea (M9)}

A solution of 3,5-dimethylbenzoic acid $(2.0 \mathrm{~g}, 13.3 \mathrm{mmol})$ in toluene $(50 \mathrm{~mL})$ and thionyl chloride $(1.1 \mathrm{~mL}, 14.6$ mmol) was heated to reflux at $80{ }^{\circ} \mathrm{C}$ for $16 \mathrm{~h}$. The excess thionyl chloride was distilled off by the azeotropic distillation with toluene under reduced pressure, affording 3,5-dimethylbenzoyl chloride as brownish oil quantitatively. The product was used in the next step without further purification. The acid derivative ( $2.24 \mathrm{~g}, 13.3$ $\mathrm{mmol})$ in dry $\mathrm{CH} 2 \mathrm{Cl} 2(20 \mathrm{~mL})$ was added dropwise over $1.5 \mathrm{~h}$ to a solution of 4,4'-ethylenedianiline $(6.20 \mathrm{~g}, 29.2$ mmol) and $\mathrm{Et}_{3} \mathrm{~N}(3.7 \mathrm{~mL}, 26.6 \mathrm{mmol})$ in dry $\mathrm{CH}_{2} \mathrm{Cl}_{2}(50 \mathrm{~mL})$ at ambient temperature under $\mathrm{N}_{2}$ atmosphere. The reaction mixture was stirred at ambient temperature for 16 hours. The organic phase was washed successively with sat. solution of $\mathrm{NaHCO}_{3}$ and brine, dried over $\mathrm{MgSO}_{4}$ and concentrated by evaporation under reduced pressure. The residue was purified by column chromatography (Hexane:EtOAc, $2: 1)$, affording a yellow solid. The solid $(0.5 \mathrm{~g}$, $1.45 \mathrm{mmol})$ was treated with maleic anhydride $(0.14 \mathrm{~g}, 1.45 \mathrm{mmol})$ in THF $(15 \mathrm{~mL})$ and stirred at ambient 
temperature under $\mathrm{N}_{2}$ atmosphere for 3 hours. The yellow precipitate $(66 \%)$ was filtered and carried out to the next step without further purification. The acid derivative obtained $(0.34 \mathrm{~g}, 0.78 \mathrm{mmol})$ was dissolved in dry $\mathrm{CH}_{3} \mathrm{CN}(20$ $\mathrm{mL})$ and refluxed for $2 \mathrm{~h}$ after the subsequent addition of $\mathrm{ZnBr}_{2}(0.18 \mathrm{~g}, 10.78 \mathrm{mmol})$ and hexamethyldisilazone $(0.83 \mathrm{~mL}, 3.91 \mathrm{mmol})$. The reaction mixture was filtered and the filtrate was reduced to $10 \%$. The solution was acidified with $0.5 \mathrm{M} \mathrm{HCl}$ until $\mathrm{pH} 1$ and extracted into $\mathrm{CH}_{2} \mathrm{Cl}_{2}$. The organic layers were combined and dried over $\mathrm{MgSO}_{4}$. The solvent was evaporated to give the desired product as yellow crystalline solid (96\%).

\section{Synthesis of 2-(4-(2,5-dioxo-2H-pirol-1(5H)-yl)phenyll) acetic acid (M10)}

Maleic anhydride $(6.05 \mathrm{~g}, 40 \mathrm{mmol}, 1 \mathrm{eq})$ and 4-aminophenyl acetic acid (3.92 g, $40 \mathrm{mmol}, 1 \mathrm{eq})$ were dissolved in acetic acid $(200 \mathrm{~mL})$ and stirred under $\mathrm{N}_{2}$ at RT for 2 hours before refluxing for 2 hours. The solvent was then evaporated under vacuum and the residue was dissolved in 5\% acetic acid in $\mathrm{CH}_{2} \mathrm{Cl}_{2}$. The solution was passed through a plug of silica eluted with $5 \%$ acetic acid in $\mathrm{CH}_{2} \mathrm{Cl}_{2}$. The fractions containing product as identified by tlc were combined and the solvent removed under vacuum. The residue was then purified by recrystallisation by using chloroform to yield the product as a yellow powder (36\%).

\section{Synthesis of 3,5-dimethyl-N-(4-(2,5-dioxo-2H-pirol-1(5H)-yl)phenyl)benzamide (M11)}

Cyanuric fluoride $(0.85 \mathrm{~mL}, 10.1 \mathrm{mmol})$ was added dropwise to a solution of 3,5-dimethylbenzoic acid $(1.52 \mathrm{~g}, 10.1$ $\mathrm{mmol})$ and dry pyridine $(0.82 \mathrm{~mL}, 10.1 \mathrm{mmol})$ in dry $\mathrm{CH}_{2} \mathrm{Cl}_{2}(40 \mathrm{~mL})$ at $0{ }^{\circ} \mathrm{C}$ under a $\mathrm{N}_{2}$ atmosphere. The reaction mixture was stirred at $0{ }^{\circ} \mathrm{C}$ for $20 \mathrm{~min}$ and then at ambient temperature for a further hour. The reaction mixture was diluted with $\mathrm{CH}_{2} \mathrm{Cl}_{2}$. The organic layer was washed with saturated $\mathrm{NaCl}$ solution, dried $\left(\mathrm{MgSO}_{4}\right)$ and the solvent was removed by evaporation under reduced pressure to afford a yellow solid $(100 \%)$. The solid $(1.52 \mathrm{~g}, 10.0 \mathrm{mmol})$ was then dissolved in dry $\mathrm{CH}_{2} \mathrm{Cl}_{2}(40 \mathrm{~mL})$ was added dropwise (over $4 \mathrm{~h}$ ) to a solution of 1,4phenylenediamine (3.26 g, $30.1 \mathrm{mmol})$ in dry $\mathrm{CH}_{2} \mathrm{Cl}_{2}(60 \mathrm{~mL})$, under a $\mathrm{N}_{2}$ atmosphere. The reaction mixture was stirred at ambient temperature overnight, and then diluted with $\mathrm{CH}_{2} \mathrm{Cl}_{2}$. The organic layer was washed successively with saturated $\mathrm{NaHCO}_{3}$ solution and saturated $\mathrm{NaCl}$ solution, dried $\left(\mathrm{MgSO}_{4}\right)$ and concentrated by evaporation under reduced pressure. The residue was purified by column chromatography $\left(\mathrm{SiO}_{2}\right.$, gradient from 100:0 to $\left.95: 5 \mathrm{CH}_{2} \mathrm{Cl}_{2} / \mathrm{MeOH}\right)$ to give a yellow solid $(80 \%)$. The solid $(0.95 \mathrm{~g}, 3.95 \mathrm{mmol})$ obtained was dissolved in acetic acid $(70 \mathrm{~mL})$ to react with maleic anhydride $(388 \mathrm{mg}, 3.96 \mathrm{mmol})$. The reaction mixture was stirred at ambient temperature under a $\mathrm{N}_{2}$ atmosphere for $6 \mathrm{~h}$, and then heated to reflux for $16 \mathrm{~h}$. The solvent was removed by evaporation under reduced pressure. The residue was purified by column chromatography ( $\mathrm{SiO} 2$, gradient from 100:0 to $98: 2 \mathrm{CHCl}_{3} / \mathrm{MeOH}$ ) to give a yellow solid (66\%).

\section{Antimicrobial screening}

All samples were tested using disc diffusion method against Escherichia coli (Gram negative), Bacillus subtilis (Gram positive) and Saccharomyces cerevisiae. The samples were prepared in two concentrations, $1.0 \mu \mathrm{g} / \mu \mathrm{L}$ (10 $\mu \mathrm{g} /$ disc) and $2.0 \mu \mathrm{g} / \mu \mathrm{L}(20 \mu \mathrm{g} /$ disc) by dissolving the solid samples in appropriate solvent. The positive control for the bacteria was streptomycin at $10 \mu \mathrm{g} /$ disc while nystatin at $20 \mu \mathrm{g} / \mathrm{disc}$ was used as positive control for the yeast. Nutrient agar and potato dextrose agar were prepared by dissolving the premixed powder in water following with heating and auto-clave. The dissolved solution was then poured on petri dishes, allowed to dry and ready to be used. The bacteria cultures were then spread on the surface of the Nutrient Agar (NA) and yeast cultures on Potato Dextrose Agar (PDA). Subsequently, the discs were impregnated with $(10 \mu \mathrm{g} / \mathrm{disc})$ and $(20 \mu \mathrm{g} / \mathrm{disc})$ test samples and then placed on the surface of the agar media. Experimental plates of bacteria cultures were incubated at $37{ }^{\circ} \mathrm{C}$ for 18 to 21 hours whereas the experimental plates of yeast cultures were incubated for 48 hours at $30{ }^{\circ} \mathrm{C}$. The antimicrobial activity was the determined by measuring the diameter of inhibition zone (IZ) and compared with positive control.

\footnotetext{
Results and Discussion

Characterization study: N-(2-methylphenyl)maleimide (M1)

M.p. $=150.6-150.8{ }^{\circ} \mathrm{C} ;{ }^{1} \mathrm{H}$ NMR $\left(400 \mathrm{MHz}, \mathrm{CDCl}_{3}\right):{ }^{\delta} \mathrm{H} 7.34(1 \mathrm{H}, \mathrm{d}, J=6.20 \mathrm{~Hz}, \mathrm{Ar} H), 7.33(1 \mathrm{H}, \mathrm{d}, J=6.24 \mathrm{~Hz}$, $\mathrm{ArH}), 7.29(1 \mathrm{H}, \mathrm{d}, J=7.72 \mathrm{~Hz}, \operatorname{Ar} H), 7.10(1 \mathrm{H}, \mathrm{d}, J=7.68 \mathrm{~Hz}, \operatorname{Ar} H), 6.85(2 \mathrm{H}, \mathrm{s}, \operatorname{Ar} H), 2.15\left(3 \mathrm{H}, \mathrm{s}, \mathrm{CH}_{3}\right) ;{ }^{13} \mathrm{C}$ NMR $\left(100 \mathrm{MHz} ; \mathrm{CDCl}_{3}\right)^{\delta} \mathrm{C} 169.7(C=\mathrm{O}), 136.6(C=C), 134.5(\mathrm{q}, 131.3(\operatorname{ArC}), 130.0(\operatorname{ArC}), 129.5(\operatorname{ArC}), 128.8$ $(\mathrm{ArC}), 126.9$ (q, $17.9\left(\mathrm{CH}_{3}\right)$; MS (EI) m/z $187.2\left(\mathrm{M}^{+}, 100 \%\right)$; IR $v_{\max }(\mathrm{KBr}) \mathrm{cm}-1: 2929.45 \mathrm{~cm}^{-1}\left(\mathrm{sp}{ }^{3} \mathrm{CH}\right), 1702.31$ $\mathrm{cm}^{-1}(\mathrm{C}=\mathrm{O}), 1029.23 \mathrm{~cm}^{-1}(\mathrm{C}-\mathrm{N})$.
} 


\section{N-(3-methylphenyl)maleimide (M2)}

${ }^{1} \mathrm{H}$ NMR $\left(400 \mathrm{MHz}, \mathrm{CDCl}_{3}\right):{ }^{\delta} \mathrm{H} 7.34(1 \mathrm{H}, \mathrm{t}, J=7.70 \mathrm{~Hz}, \operatorname{Ar} H), 7.17(1 \mathrm{H}, \mathrm{d}, J=7.72 \mathrm{~Hz}, \operatorname{Ar} H), 7.11(1 \mathrm{H}, \mathrm{d}, J=$ $8.44 \mathrm{~Hz}, \mathrm{Ar} H), 7.11(1 \mathrm{H}, \mathrm{d}, J=8.44 \mathrm{~Hz}, \mathrm{ArH}), 6.80(2 \mathrm{H}, \mathrm{s}, \mathrm{ArH}), 2.37\left(3 \mathrm{H}, \mathrm{s}, \mathrm{CH}_{3}\right) ;{ }^{13} \mathrm{C}$ NMR $\left(100 \mathrm{MHz} ; \mathrm{CDCl}_{3}\right)$ ${ }^{\delta} \mathrm{C} 169.7(C=\mathrm{O}), 139.3(\mathrm{ArC}), 134.2$ (q, $131.1(\mathrm{ArC}), 129.0(\mathrm{ArC}), 128.9(\mathrm{ArC}), 126.9\left(\mathrm{q}, 123.4(\mathrm{ArC}), 21.4\left(C \mathrm{H}_{3}\right)\right.$; MS (EI) m/z $187.2\left(\mathrm{M}^{+}, 100 \%\right)$; IR $v_{\max }(\mathrm{KBr}) \mathrm{cm}-1: 2922.57 \mathrm{~cm}^{-1}\left(\mathrm{sp}^{3} \mathrm{CH}\right), 1705.59 \mathrm{~cm}^{-1}(\mathrm{C}=\mathrm{O}), 1033.45 \mathrm{~cm}^{-1}(\mathrm{C}-$ $\mathrm{N})$.

\section{N-(4-methylphenyl)maleimide (M3)}

M.p. $=150.5-150.7{ }^{\circ} \mathrm{C} ;{ }^{1} \mathrm{H}$ NMR $\left(400 \mathrm{MHz}\right.$, d-Acetone): ${ }^{\delta} \mathrm{H} 7.27(2 \mathrm{H}, \mathrm{d}, J=8.08 \mathrm{~Hz}, \mathrm{ArH}), 7.22(2 \mathrm{H}, \mathrm{d}, J=8.44$ $\mathrm{Hz}, \mathrm{ArH}), 7.00(2 \mathrm{H}, \mathrm{s}, \mathrm{ArH}), 2.35(3 \mathrm{H}, \mathrm{s}, \mathrm{CH}) ;{ }^{13} \mathrm{C}$ NMR $(100 \mathrm{MHz} ;$ d-Acetone $){ }^{\delta} \mathrm{C} 169.8(C=\mathrm{O}), 137.4(\mathrm{ArC})$, 134.4 (q, 129.5 (ArC), $129.3(\mathrm{ArC}), 126.5$ (q, $20.0\left(\mathrm{CH}_{3}\right)$; MS (EI) m/z 187.1 (M+1 $\left.100 \%\right)$; IR v $\max (\mathrm{KBr}) \mathrm{cm}-1$ : $3450.67 \mathrm{~cm}^{-1}(\mathrm{OH}), 2967.11 \mathrm{~cm}^{-1}\left(\mathrm{sp}^{3} \mathrm{CH}\right), 1702.41 \mathrm{~cm}^{-1}(\mathrm{C}=\mathrm{O}), 1041.54 \mathrm{~cm}^{-1}(\mathrm{C}-\mathrm{N})$.

\section{$N$-(4-florophenyl)maleimide (M4)}

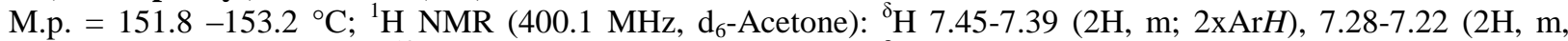
2×ArH), $7.03(2 \mathrm{H}, \mathrm{s}, \mathrm{ArH}) ;{ }^{13} \mathrm{C} \mathrm{NMR}\left(100.6 \mathrm{MHz}, \mathrm{d}_{6}\right.$-DMSO): ${ }^{\delta} \mathrm{C} 169.7(\mathrm{C}=\mathrm{O}), 161.6(C \mathrm{~F}), 134.5(\mathrm{ArCH}), 128.7$ $(\mathrm{ArCH}), 128.3(\mathrm{ArC}-\mathrm{N}), 115.6(\mathrm{ArCH})$.

N-(4-chlorophenyl)maleimide (M5)

M.p. $=106.7-108.5{ }^{\circ} \mathrm{C} ;{ }^{1} \mathrm{H}$ NMR (400.1 MHz, d 6 -Acetone): ${ }^{\delta} \mathrm{H} 7.53-7.51$ (2H, m; 2xArH), 7.43-7.41 (2H, m, $2 \times \mathrm{ArH}), 7.04(2 \mathrm{H}, \mathrm{s}, \mathrm{Ar} H) ;{ }^{13} \mathrm{C}$ NMR (100.6 MHz, d $\left.-\mathrm{DMSO}\right):{ }^{\delta} \mathrm{C} 169.4(C=\mathrm{O}), 134.6(\mathrm{ArCH}), 132.6(\mathrm{ArC}-\mathrm{N})$, $131.1(\mathrm{ArC}-\mathrm{Cl}), 128.9(\mathrm{ArCH}), 128.0(\mathrm{ArCH}) ;{ }^{19} \mathrm{~F}$ NMR $\left(376.5 \mathrm{MHz}, d_{6}\right.$-DMSO) : ${ }^{\delta} \mathrm{F} 115.6(\mathrm{ArC}-\mathrm{F})$.

\section{$N$-(4-bromophenyl)maleimide (M6)}

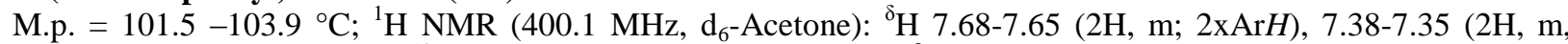
$2 \times \mathrm{ArH}), 7.04(2 \mathrm{H}, \mathrm{s}, \mathrm{ArH}) ;{ }^{13} \mathrm{C}$ NMR (100.6 MHz, d ${ }_{6}$-DMSO): ${ }^{\delta} \mathrm{C} 169.4(\mathrm{C}=\mathrm{O}), 134.6(\mathrm{ArCH}), 131.9(\mathrm{ArCH})$, $131.5(\mathrm{ArC}-\mathrm{N}), 128.3(\mathrm{ArCH}), 120.6(C-\mathrm{Br})$.

1-(3,5-bis(trifloromethyl)phenyl)-3-(4-(3-(2,5-dioxo-2H-pirol-1(5H)-yl)phenetyl)phenyl)urea (M8)

M.p. $=205.3-208.3{ }^{\circ} \mathrm{C} ;{ }^{1} \mathrm{H}$ NMR $\left(300.1 \mathrm{MHz}, d_{6}\right.$-DMSO) : ${ }^{\delta} \mathrm{H} 9.36(1 \mathrm{H}, \mathrm{s} ; \mathrm{NH}), 8.89(1 \mathrm{H}, \mathrm{s}, \mathrm{NH}), 8.13(2 \mathrm{H}, \mathrm{s}$; $2 \times \mathrm{ArH}), 7.61(1 \mathrm{H}, \mathrm{s} ; \mathrm{Ar} H), 7.39\left(2 \mathrm{H}, \mathrm{d},{ }^{3} J_{\mathrm{HH}} 8.4 \mathrm{~Hz} ; 2 \times \mathrm{ArH}\right), 7.33\left(2 \mathrm{H}, \mathrm{d},{ }^{3} J_{\mathrm{HH}} 8.4 \mathrm{~Hz} ; 2 \times \mathrm{Ar} H\right), 7.22\left(2 \mathrm{H}, \mathrm{d},{ }^{3} J_{\mathrm{HH}}\right.$ $8.4 \mathrm{~Hz} ; 2 \times \mathrm{ArH}), 7.18\left(2 \mathrm{H}, \mathrm{d},{ }^{3} J_{\mathrm{HH}} 8.4 \mathrm{~Hz} ; 2 \times \mathrm{ArH}\right), 7.16(2 \mathrm{H}, \mathrm{s} ; 2 \times \mathrm{CH}), 2.94-2.82\left(4 \mathrm{H}, \mathrm{m} ; 2 \times \mathrm{CH}_{2}\right) ;{ }^{13} \mathrm{C} \mathrm{NMR}$ (75.5 MHz, $d_{6}$-DMSO): ${ }^{\delta} \mathrm{C} 170.0(C=\mathrm{O}), 152.4(C=\mathrm{O}), 142.0(\mathrm{ArC}), 141.3(\mathrm{ArC}), 136.8(\mathrm{ArC}), 135.5(\mathrm{ArC}), 134.6$ $(\mathrm{ArCH}), 130.7\left(\mathrm{q},{ }^{2} J_{\mathrm{CF}} 32.7 \mathrm{~Hz}, \mathrm{ArC}\right), 129.3(\mathrm{ArC}), 128.8(\mathrm{ArCH}), 128.7(\mathrm{ArCH}), 126.6(\mathrm{CH}), 123.3\left(\mathrm{q},{ }^{1} J_{\mathrm{CF}} 272.3\right.$ $\left.\mathrm{Hz}, \mathrm{CF}_{3}\right), 119.0(\mathrm{ArCH}), 117.8(\mathrm{~m} ; \mathrm{ArCH}), 114.2(\mathrm{~m}, \mathrm{ArCH}), 36.7\left(\mathrm{CH}_{2}\right), 36.3\left(\mathrm{CH}_{2}\right) ;{ }^{19} \mathrm{~F} \mathrm{NMR}\left(376.5 \mathrm{MHz}, d_{6}{ }^{-}\right.$ DMSO) : ${ }^{\delta} \mathrm{F}-62.2\left(\mathrm{ArCF}_{3}\right) ; \mathrm{MS}\left(\mathrm{ES}^{-}\right) \mathrm{m} / z 546\left([\mathrm{M}-\mathrm{H}]^{-}, 100\right) ;$ HRMS $\left(\mathrm{ES}^{-}\right) \mathrm{m} / z$ calculated for $\mathrm{C}_{27} \mathrm{H}_{18} \mathrm{~N}_{3} \mathrm{O}_{3} \mathrm{~F}_{6}$ $[\mathrm{M}-\mathrm{H}]^{-}$546.1252, found 546.1257.

\section{1-(4-(4-(2,5-dioxo-2H-pirol-1(5H)-yl)phenetyl)phenyl)-3-(3,5-dimethylphenyl)urea (M9)}

M.p. $=229.3-231.4{ }^{\circ} \mathrm{C} ;{ }^{1} \mathrm{H}$ NMR $\left(400.1 \mathrm{MHz} \mathrm{CDCl}_{3}\right):{ }^{\delta} \mathrm{H} 7.81(1 \mathrm{H}, \mathrm{s} ; \mathrm{NH}), 7.57-7.54(2 \mathrm{H}, \mathrm{m} ; 2 \times \mathrm{ArH}), 7.46$ $(2 \mathrm{H}, \mathrm{s} ; 2 \times \mathrm{ArH}), 7.29-7.27(2 \mathrm{H}, \mathrm{m} ; 2 \times \mathrm{ArH}), 7.25-7.22(2 \mathrm{H}, \mathrm{m} ; 2 \times \mathrm{ArH}), 7.19-7.17(3 \mathrm{H}, \mathrm{m} ; 3 \times \mathrm{ArH}), 6.84(2 \mathrm{H}$, $\mathrm{s} ; 2 \times \mathrm{CH}), 2.97-2.89\left(4 \mathrm{H}, \mathrm{m} ; 2 \times \mathrm{CH}_{2}\right), 2.38\left(6 \mathrm{H}, \mathrm{s} ; 2 \times \mathrm{CH}_{3}\right) ;{ }^{13} \mathrm{C} \mathrm{NMR}\left(100.6 \mathrm{MHz}, \mathrm{CDCl}_{3}\right):{ }^{\delta} \mathrm{C} 169.8(C=\mathrm{O}), 166.1$ $(C=\mathrm{O}), 141.8(\mathrm{ArC}), 138.6(\mathrm{ArC}), 137.7(\mathrm{ArC}), 136.2(\mathrm{ArC}), 135.2(\mathrm{ArC}), 134.3(C \mathrm{H}), 133.5(\mathrm{ArCH}), 129.4$ $(\mathrm{ArCH}), 129.2(\mathrm{ArC}), 129.1(\mathrm{ArCH}), 126.1(\mathrm{ArCH}), 124.9(\mathrm{ArCH}), 120.4(\mathrm{ArCH}), 37.7\left(\mathrm{CH}_{2}\right), 37.3\left(\mathrm{CH}_{2}\right), 21.4$ $\left(\mathrm{CH}_{3}\right) ; \mathrm{MS}\left(\mathrm{ES}^{+}\right) \mathrm{m} / z 447\left([\mathrm{M}+\mathrm{Na}]^{+}, 75\right), 479(100)$; HRMS (ES $\left.{ }^{+}\right) \mathrm{m} / z$ calculated for $\mathrm{C}_{27} \mathrm{H}_{24} \mathrm{~N}_{2} \mathrm{O}_{3} \mathrm{Na}[\mathrm{M}+\mathrm{Na}]^{+}$ 447.1685, found 447.1674 .

\section{2-(4-(2,5-dioxo-2H-pirol-1(5H)-yl)phenyll) acetic acid (M10)}

M.p. $=160.0-162.0{ }^{\circ} \mathrm{C} ;{ }^{1} \mathrm{H}$ NMR (400.1 MHz, d 6 -DMSO): ${ }^{\delta} \mathrm{H} 12.07\left(1 \mathrm{H}, \mathrm{s}, \mathrm{CO}_{2} H\right), 7.36\left(2 \mathrm{H}, \mathrm{d},{ }^{3} \mathrm{~J}_{\mathrm{HH}}=8.5 \mathrm{~Hz}\right.$, $2 \times \mathrm{ArH}), 7.26\left(2 \mathrm{H}, \mathrm{d},{ }^{3} \mathrm{~J}_{\mathrm{HH}}=8.5 \mathrm{~Hz} 2 \times \mathrm{ArH}\right), 7.18(2 \mathrm{H}, \mathrm{s}, 2 \times \mathrm{CH}), 3.63\left(2 \mathrm{H}, \mathrm{s}, \mathrm{CH}_{2}\right) ;{ }^{13} \mathrm{C} \mathrm{NMR}\left(100.6 \mathrm{MHz}, \mathrm{d}_{6}{ }^{-}\right.$ DMSO): ${ }^{\delta} \mathrm{C} 172.5\left(\mathrm{CO}_{2} \mathrm{H}\right), 169.3(C=\mathrm{O}), 134.7(\mathrm{ArC}-\mathrm{N}), 134.6(C \mathrm{H}), 130.0(\mathrm{ArC}), 129.9(\mathrm{ArCH}), 126.6(\mathrm{ArCH})$, 
$40.1\left(\mathrm{CH}_{2}\right) ; \mathrm{MS}\left(\mathrm{EI}^{+}\right) \mathrm{m} / z, 254\left([\mathrm{M}+\mathrm{Na}]^{+}, 100\right)$; HRMS $\left(\mathrm{EI}^{+}\right) \mathrm{m} / z$ calculated for $\mathrm{C}_{12} \mathrm{H}_{9} \mathrm{NO}_{4}[\mathrm{M}+\mathrm{Na}]^{+} 254.0429$, found 254.0434 .

\section{3,5-dimethyl-N-(4-(2,5-dioxo-2H-pirol-1(5H)-yl)phenyl)benzamide (M11)}

${ }^{1} \mathrm{H}$ NMR $\left(300.1 \mathrm{MHz}, \mathrm{CDCl}_{3}\right):{ }^{8} \mathrm{H}=7.86(1 \mathrm{H}, \mathrm{s}, \mathrm{NH}), 7.79-7.74(2 \mathrm{H}, \mathrm{m}, \mathrm{ArH}), 7.47(2 \mathrm{H}, \mathrm{s}, \mathrm{ArH}), 7.37-7.32(2 \mathrm{H}$, $\mathrm{m}, \mathrm{ArH}), 7.19(1 \mathrm{H}, \mathrm{s}, \mathrm{ArH}), 6.85(2 \mathrm{H}, \mathrm{s}, \mathrm{ArH}), 2.39\left(6 \mathrm{H}, \mathrm{d}, \mathrm{J}=0.5 \mathrm{~Hz}, \mathrm{CH}_{3}\right) ;{ }^{13} \mathrm{C} \mathrm{NMR}\left(75.5 \mathrm{MHz}, \mathrm{CDCl}_{3}\right):{ }^{8} \mathrm{C}=$ $169.7(C=\mathrm{O}), 166.2(\mathrm{CONH}), 138.8(\mathrm{ArC}), 137.9(\mathrm{ArC}), 134.8(\mathrm{ArC}), 134.4(\mathrm{ArCH}), 133.8(\mathrm{ArCH}), 127.2(\operatorname{ArC})$, $126.9(\mathrm{ArCH}), 124.9(\mathrm{ArCH}), 120.6(\mathrm{ArCH}), 21.4\left(\mathrm{CH}_{3}\right) ; \mathrm{MS}\left(\mathrm{ES}^{+}\right): \mathrm{m} / \mathrm{z}(\%)=321\left([\mathrm{M}+\mathrm{H}]^{+}, 100\right), 375(70)$; HRMS $\left(\right.$ ES $\left.^{+}\right): \mathrm{m} / \mathrm{z}$ calc. for $[\mathrm{M}+\mathrm{H}]^{+} \mathrm{C}_{19} \mathrm{H}_{17} \mathrm{~N}_{2} \mathrm{O}_{3} 321.1239$, found 321.1237 .

The structure of the 11 maleimide compounds as shown in the following Table 2 .

Table 2. Structure of eleven $N$-substituted maleimides

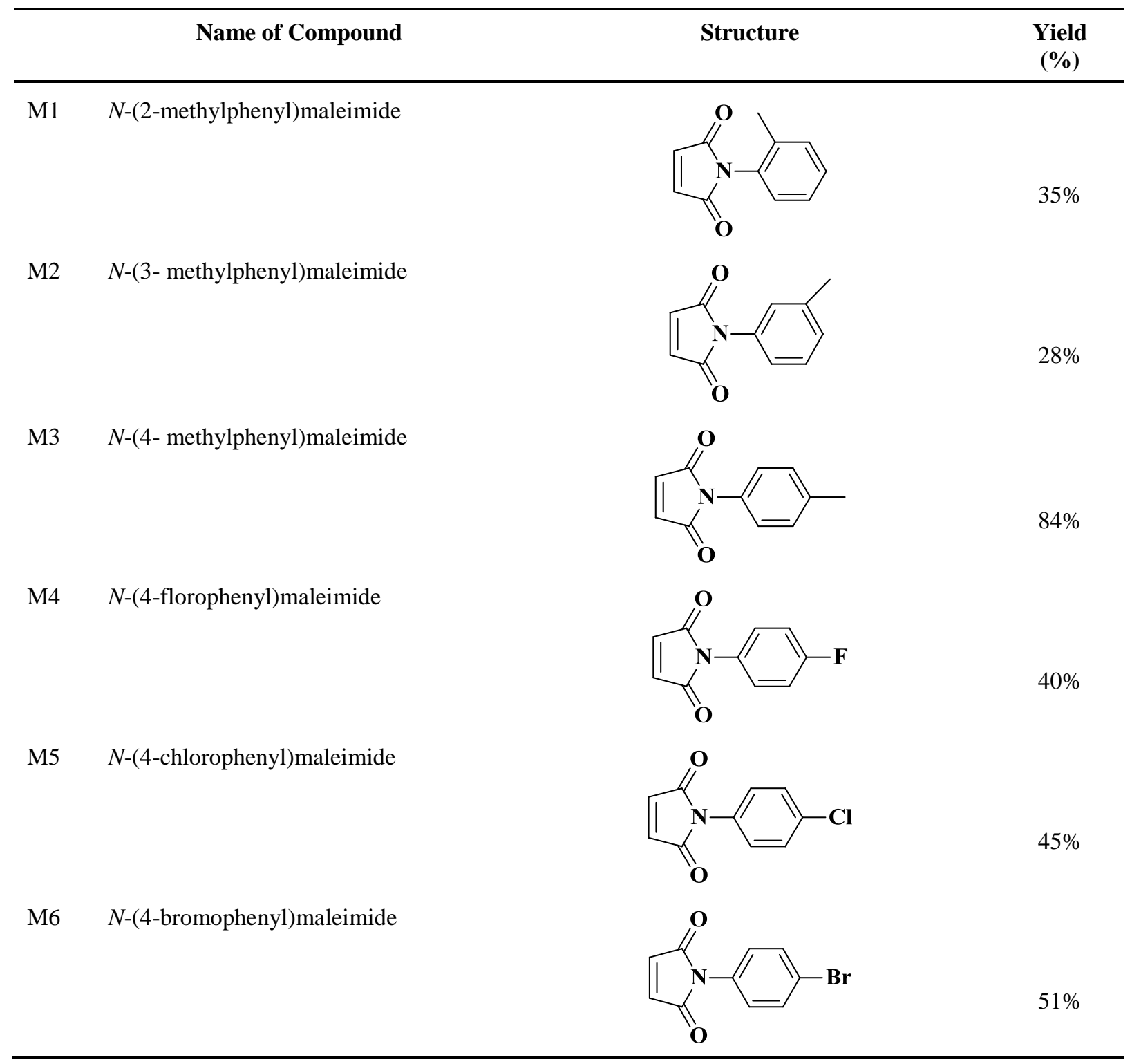


Table 2 (cont'd). Structure of eleven $N$-substituted maleimides

Name of Compound
M7 Maleimide
M9 1-(3,5-bis(trifloromethyl)phenyl)-3-(4-)
$\begin{aligned} & \text { (3-(2,5-dioxo-2H-pirol-1(5H)- } \\ & \text { yl)phenetyl)phenyl)urea } \\ & \text { 1-(4-(4-(2,5-dioxo-2Hent)phenyl)-3-(3,5- } \\ & \text { dimethylphenyl)urea }\end{aligned}$
M10 2-(4-(2,5-dioxo-2H-pirol-1(5H)-
yl)phenyll) acetic acid
$\begin{aligned} & \text { 3,5-dimethyl-N-(4-(2,5-dioxo-2H- } \\ & \text { pirol-1(5H)-yl)phenyl)benzamide }\end{aligned}$

The $N$-substituted maleimides M1 to M11 were tested against two bacterial strains and a yeast. The biological screening activity of the studied compounds were determined by disc diffusion method. Data shown in Table 3 indicate that all compounds exhibited notable antibacterial and antifungal activity except M8, M9 and M11.

According to Table 3, the reactivity of M1, M2 and M3 toward all three microbes tested were positive, showing inhibition zone ranging from $9 \mathrm{~mm}$ to $21 \mathrm{~mm}$ for sample concentration up to $20 \mu \mathrm{g} / \mathrm{disc}$. Whereas, the inhibition zone for M4, M5 and M6 were around $10 \mathrm{~mm}$, except for M5 at $20 \mu \mathrm{g} / \mathrm{disc}$ showed $18 \mathrm{~mm}$ inhibition zone on the yeast, Saccharomyces cerevisiae. Surprisingly, M4 which showed inhibition towards Escherichia coli at $10 \mu \mathrm{g} / \mathrm{disc}$, became inactive when the concentration double up to $20 \mu \mathrm{g} / \mathrm{disc}$. On the other hand, unsubstituted maleimide, M7 is very reactive towards Saccharomyces cerevisiae. M8 possess a trifluoromethane moiety which is often used to increase the biological stability of a drug. Nonetheless, our finding indicated that samples M8 to M11 are generally unreactive, except that M10 showed a small inhibition zone of $9 \mathrm{~mm}$ towards Saccharomyces cerevisiae. 
Generally, most of the samples were biologically active against the yeast Saccharomyces cerevisiae compared to Escherichia coli and Bacillus subtilis. It is also noted that the biological reactivity of the samples does not directly proportional to the dosage concentration. This might be due to the reason that maleimide compounds only show optimum biological reactivity at optimum dosage. Hence, any concentrations beyond the optimum range would have no effect against the microbes tested. Fascinatingly, maleimides substituted with methyl phenyl group are among the most reactive compounds tested. Their inhibition zone is comparable to that of the positive control.

Table 3. Biological activity of $N$-substituted maleimide towards three microbes

\begin{tabular}{|c|c|c|c|c|c|c|}
\hline \multirow[t]{3}{*}{ Compound } & \multicolumn{6}{|c|}{ Inhibition Zone (mm) } \\
\hline & \multicolumn{2}{|c|}{ Escherichia coli } & \multicolumn{2}{|c|}{ Bacillus subtilis } & \multicolumn{2}{|c|}{ Saccharomyces cerevisiae } \\
\hline & $10 \mu \mathrm{g} / \mathrm{disc}$ & $20 \mu \mathrm{g} / \mathrm{disc}$ & $10 \mu \mathrm{g} / \mathrm{disc}$ & $20 \mu \mathrm{g} / \mathrm{disc}$ & $10 \mu \mathrm{g} / \mathrm{disc}$ & $20 \mu \mathrm{g} / \mathrm{disc}$ \\
\hline M1 & 15 & 15 & 10 & 15 & 21 & 18 \\
\hline M2 & 11 & 13 & 11 & 12 & 15 & 19 \\
\hline M3 & 10 & 11 & 9 & 10 & 12 & 14 \\
\hline M4 & 10 & - & 10 & 11 & 10 & 10 \\
\hline M5 & 9 & 12 & 11 & 12 & 15 & 18 \\
\hline M6 & 8 & 10 & 10 & 10 & 12 & 10 \\
\hline M7 & 22 & 25 & 21 & 25 & 30 & 29 \\
\hline M8 & - & - & - & - & - & - \\
\hline M9 & - & - & - & - & - & - \\
\hline M10 & - & - & - & - & - & 9 \\
\hline M11 & - & - & - & - & - & - \\
\hline Negative control & - & - & - & - & - & - \\
\hline Streptomycin $10 \mu \mathrm{g}$ & 16 & NA & 15 & NA & NA & NA \\
\hline Nystatin $20 \mu \mathrm{g}$ & NA & NA & NA & NA & NA & - \\
\hline
\end{tabular}

Note: Experiments are done in triplicate to rule out experimental bias or random error.

In addition, unsubstituted maleimide was more reactive towards the microbes compared to the $N$-substituted maleimide since the maleimide core itself is the main active centre which possess good biological activites [15]. Thus, it is apparent that the introduction of bulky substituents at the $N$ position of the maleimide ring had different influence on the biological activities. A possible explanation is that maleimide and derivatives could inactivate some enzymes in the microbes. With change in the polarity and chain length of $N$-phenyl substituents, their capacity to bind to eznyme differs and therefore also had different influence on biological activities.

\section{Conclusion}

In conclusion, the present work has demonstrated that unsubstituted maleimide was most reactive while simple $N$ phenyl substituted maleimide exhibit potential activity against the tested microbes. Nevertheless, bulky $N$-phenyl substituted maleimides were biologically inactive with rapid decreasing action towards the microbe when more complex moieties inserted. This might be explained by the nitrogen-carbon distances between the two rings which play an important role in the antimicrobial activities of these compounds. Furthermore, steric hindrance might affect inhibition activity. For further investigation, more sensitive antimicrobe screening method such as dilution method should be used to evaluate the potential of maleimide derivatives against different types of microbes. Structural optimisation of these compounds are underway. 


\section{Acknowledgement}

The authors would like to thank Universiti Kebangsaan Malaysia, for the research grant GUP-2014-016, DIP-2015015 and facilities provided by PPSKTM and everyone who has helped in this research.

\section{References}

1. Beović, B. (2006). The issue of antimicrobial resistance in human medicine. International Journal of Food Microbiology, 112(3): $280-287$.

2. Salewska, N., Boros-Majewska, J., Łcka, I., Chylińska, K., Sabisz, M., Milewski, S. and Milewska, M. J. (2012). Chemical reactivity and antimicrobial activity of n-substituted maleimides. Journal of Enzyme Inhibition and Medicinal Chemistry, 27(1): 117 - 124.

3. Prado, S. R. T., Cechinel-Filho, V., Campos-Buzzi, F., Corrêa, R., Cadena, S. M. C. S. and De Oliveira, M. B. M. (2004). Biological evaluation of some selected cyclic imides: mitochondrial effects and in vitro cytotoxicity. Zeitschrift fur Naturforschung - Section C Journal of Biosciences, 59(9-10): 663 -672.

4. Bansode, T. N., Shelke, J. V. and Dongre, V. G. (2009). Synthesis and antimicrobial activity of some new nacyl substituted phenothiazines. European Journal of Medicinal Chemistry, 44(12): 5094 -5098.

5. Ye, Q., Cao, J., Zhou, X., Lv, D., He, Q., Yang, B. and Hu, Y. (2009). Synthesis and evaluation of novel 7azaindazolyl-indolyl-maleimide derivatives as antitumor agents and protein kinase $\mathrm{C}$ inhibitors. Bioorganic \& Medicinal Chemistry, 17(13): 4763 - 4772.

6. Mahle, F., Da Rosa Guimarães, T., Vergilina Meira, A., Corrêa, R., Bella Cruz, R. C., Bella Cruz, A., Nunes, R. J., Cechinel-Filho, V. and De Campos-Buzzi, F. (2010). Synthesis and biological evaluation of n-antipyrine4-substituted amino-3-chloromaleimide derivatives. European Journal of Medicinal Chemistry, 45(11): 4761 4768.

7. Li, W., Fan, Y., Shen, Z., Chen, X. and Shen, Y. (2012). Antifungal activity of simple compounds with maleic anhydride or dimethylmaleimide structure against Botrytis Cinerea. Journal of Pesticide Science, 37(3): 247 251.

8. Sortino, M., Cechinel Filho, V., Corrêa, R. and Zacchino, S. (2008). N-Phenyl and N-Phenylalkyl-maleimides acting against candida spp.: time-to-kill, stability, interaction with maleamic acids. Bioorganic and Medicinal Chemistry, 16(1): $560-568$.

9. Zentz, F., Valla, A., Le Guillou, R., Labia, R., Mathot, A. G. and Sirot, D. (2002). Synthesis and antimicrobial activities of n-substituted imides. Farmaco, 57(5): 421 - 426.

10. Sortino, M., Garibotto, F., Cechinel Filho, V., Gupta, M., Enriz, R. and Zacchino, S. (2011). Antifungal, cytotoxic and sar studies of a series of n-alkyl, n-aryl and n-alkylphenyl-1,4-pyrrolediones and related compounds. Bioorganic \& Medicinal Chemistry, 19(9): 2823 - 2834.

11. Xu, H., Baidoo, K. E., Wong, K. J. and Brechbiel, M. W. (2008). A novel bifunctional maleimido chx-a" chelator for conjugation to thiol-containing biomolecules. Bioorganic and Medicinal Chemistry Letters, 18(8): $2679-2683$.

12. Hayworth, D. (2014). Sulfhydryl-reactive crosslinker chemistry. http://www.piercenet.com/method/ sulfhydrylreactive-crosslinker-chemistry [4 April 2014].

13. Ye, X., Li, X., Yuan, L., Ge, L., Zhang, B. and Zhou, S. (2007). Interaction of houttuyfonate homologues with the cell membrane of gram-positive and gram-negative bacteria. Colloids and Surfaces A: Physicochemical and Engineering Aspects, 301(1-3): $412-418$.

14. López, S. N., Castelli, M. V., De Campos, F., Corrêa, R., Cechinel Filho, V., Yunes, R. A., Zamora, M. A., Enriz, R. D., Ribas, J. C., Furlán, R. L. E. and Zacchino, S. A. (2005). In Vitro antifungal properties, structureactivity relationships and studies on the mode of action of n-phenyl, n-aryl, n-phenylalkyl maleimides and related compounds. Arzneimittel-Forschung/Drug Research, 55(2): 123 - 132.

15. Xiao-Long, C., Li-Jun,Z., Fu-Ge, L., Yong-Xian, F.,Wei-Ping, W., Bao-Ju, L. and Yin-Chu, S. (2015). Synthesis and antifungal evaluation of a series of maleimides, Pest Management Science; 71: 433 - 440. 